\title{
Intensified search for energy alternatives in West Germany
}

\section{Munich}

Research Minister Heinz Riesenhuber (Christian Democrat) announced in Bonn last week that West Germany's investment in renewable energy research DM260 million for 1988 - was the largest in the world "in both absolute and relative" terms.

But many of those who support increased use of renewable energy resources are still not happy with West Germany's centre-right government. That is because the government is holding firm to nuclear power as an 'interim' energy source along with the commitment to renewable energy research. Thirty-eight per cent of West Germany's total energy use is supplied by nuclear power despite growing resistance from the press, the public and several Länder governed by the opposition Social Democrats (SPD). Renewable energy sources such as hydroelectric, solar and wind power account for 2.4 per cent of West Germany's energy consumption.

Critics also say that the government has failed to use subsidies effectively to hasten the introduction of new energy sources. One government official said that BMFT wanted more money for such subsidies but the request was refused by Economics Minister Martin Bangemann (Free Democrat, FDP). The FDP, the smallest partner in the governing coalition, opposes government subsidies.

The cost of energy in West Germany supports the federal government's continued enthusiasm for nuclear energy. According to government figures, one kilowatt-hour from a nuclear power station costs DM0.14, compared with DM0.27 for wind energy, DM3.57 for solar energy and DM0.20 for energy from coal-fired power stations.

A number of SPD-governed Länder are aggressively pursuing non-nuclear options and talking about following the decision recently made in Sweden to end reliance on nuclear power in the early twenty-first century. In the northernmost West German Land of Schleswig-Holstein, the SPD was given an absolute majority in elections on $8 \mathrm{May}$; its platform promised a shutoff of nuclear power.

Hamburg's plans to eliminate dependence on nuclear power by 1996 received a setback last year when the SPD was forced to form a governing coalition with the FDP. Hamburg has nevertheless commissioned an independent report on the economic consequences of the elimination of nuclear power which is due out in September. Hamburg relies on nuclear power for 90 per cent of its electricity.

In Saarland, a coal-mining region which uses no nuclear energy, and Schleswig-
Holstein, the SPD is working on the coupling of coal-fired electricity plants to heat exchangers which then carry the excess heat to customers through longdistance heating pipes.

Such a procedure could increase to 90 per cent the recovery of energy from coal. Traditional coal-fired power plants use only 35 per cent of the energy and release the excess heat to the atmosphere. Under such a plan, numerous small power plants would have to be built near populated areas. A pilot plant is already operating "very economically" at Flensburg, said a spokesman for the Schleswig-Holstein energy ministry.

Both Länder intend to encourage energy conservation among the population. Remarkably, the first pilot study on the effectiveness of electricity conservation in West Germany is being carried out only this year in Saarland. The government has set up an 'energy agency' to finance energy-saving home improvements and billing procedures are being changed to encourage savings.

Steven Dickman

\section{Congress provides a rundown on US biotechnology}

\section{Washington}

LAST week's release of a report by the US Office of Technology Assessment (OTA) was the highlight of a week of congressional attention to biotechnology, which featured a day-long conference and a hearing on a bill to set up boards to enhance the competitiveness of the industry.

The report, entitled US Investment in Biotechnology, is the second to examine US efforts both to encourage the growth of the biotechnology industry and to remove any federal obstacies in its path since the biotechnology industry began in earnest in the early 1980 s.

In the new report, the OTA finds that the US biotechnology enterprise is roughly equally underwritten by the federal government, which spends $\$ 2,700$ million annually on basic and "generic applied" research, and private industry, which invests nearly $\$ 2,000$ million.

For the largest sector of the biotechnology industry - that developing human pharmaceuticals - the investment is judged sufficient, with the exception of research in protein chemistry and drug delivery systems. But the key areas of agricultural biotechnology and biological waste disposal techniques are suffering from a lack of money and from regulatory barriers governing environmental releases.

State governments have become increasingly involved in attempts to foster biotechnology companies. Although their investment is only one-sixteenth of the federal government's, 33 states have either formally organized biotechnology centres to draw in large companies and incubate start-ups, or provided tax and training incentives.

Not surprisingly, biotechnology companies thrive best in the states with the strongest university research programmes in the biological sciences. OTA reports that the industrial contribution to aca- demic research is four to five times greater in biotechnology than in other fields.

The close relationship of universities and biotechnology companies has so far not led to a corruption of basic research interests or diverted academic scientists from their student education responsibilities, but OTA says collaborations may need monitoring.

The OTA report suggests that additional financing may be needed for new biotechnology companies, perhaps in the form of additional small business grants. OTA also found that the tax reform law passed in 1986, which reduced the tax credits for research and development and which abolished the lower tax rates for capital gains from the sale of research and development limited partnerships, were harming industry.

The OTA report did not bear out some of the dire predictions made by the agency in a similar report issued in 1984 . The biotechnology industry has not experienced a 'shakeout' eliminating all but the largest and most profitable companies, and there has been no serious lack of funds for applied research.

No critical shortage of personnel trained in the biological sciences and in bio-process engineering has occurred either, with the exception of microbial ecologists, who are in tight demand.

The congressional hearing held last week discussed bills that would establish national policy commissions and ethics boards to steer US biotechnology activities, including the project to sequence the human genome. A bill has already been passed in the Senate, and legislation in the House of Representatives is pending.

Biotechnology trade associations welcomed the creation of boards intended to foster their industry, but administration officials testified that another layer of bureaucracy was unnecessary and that the legislation as drafted may in fact be unconstitutional. 